\title{
PENGEMBANGAN PERANGKAT PEMBELAJARAN BERBASIS PRAKTIKUM INKUIRI UNTUK MATA PELAJARAN MENGANALISIS RANGKAIAN LISTRIK
}

\author{
Oriza Candra*, Usmeldi, Doni Tri Putra Yanto, Femypadillah Ismanto \\ Universitas Negeri Padang, Indonesia \\ *Email: orizacandra@ft.unp.ac.id \\ *Corresponden Author
}

\begin{abstract}
ABSTRAK
Penelitian ini dilatarbelakangi olah hasil observasi awal yang menunjukkan bahwa hasil pembelajaran Mengalisis Rangkaian Listrik (MRL) belum optimal yang disebabkan oleh ketidaksesuaian materi pembelajaran dengan metode pembelajaran yang diterapkan. Tujuan penelitian adalah mengembangkan perangkat pembelajaran berbasis praktikum inkuiri yang valid, praktis, dan efektif pada mata pelajaran MRL dengan materi Rangkaian Kemagnetan di SMKN 1 Padang yang terdiri dari RPP dan LKS. Jenis penelitian ini adalah penelitian pengembangan menggunakan model pengembangan 4-D yang terdiri dari 4 tahap yaitu define, design, develop, dan desseminate. Responden penelitian ini adalah siswa kelas X TDTL-B SMKN 1 Padang yang terdiri dari 29 orang siswa. Hasil analisis data didapatkan kesimpulan bahwa perangkat pembelajaran yang dikembangkan dikategorikan valid dengan tingkat kevalidan RPP dan LKS adalah $85.42 \%$ dan $87.50 \%$. Perangkat Pembelajaran yang dikembangkan dikategorikan praktis dengan tingkat kepraktisan dari guru dan siswa adalah $80 \%$ dan $86.03 \%$. Perangkat pembelajaran yang dikembangkan efektif dalam meningkatkan kompetensi siswa dengan ketuntasan klasikal untuk kompetensi kognitif, afektif, dan psikomotor adalah $89.66 \%$, 100\%, dan $100 \%$. Dengan demikian, maka dapat disimpulkan bahwa perangkat pembelajaran berbasis praktikum inkuiri yang dikembangkan merupakan perangkat pembelajaran yang valid, praktis, dan efektif.
\end{abstract}

Kata Kunci: Perangkat Pembelajaran; Praktikum Inkuiri; Menganalisis Rangkaian Listrik.

\begin{abstract}
This research is based on the results of preliminary observations which showed that the learning outcomes of Analyzing Electric Circuits (MRL) were not optimal due to the mismatch of learning material with applied learning methods. The purpose of this research was to develop a valid, practical, and effective practicum-based learning tool on MRL subjects with the Magnetic Circuit material at SMKN 1 Padang consisting of lesson Plan (RPP) and workbook (LKS). This type of research is development research using a 4-D development model consisting of 4 stages, namely defining, designing, developing, and analyzing. The respondents of this research were students of class X TDTL-B SMKN 1 Padang consisted of 29 students. The results of data analysis obtained from the developed learning tools were categorized as valid with the validity level of the RPP and LKS were $85.42 \%$ and $87.50 \%$ respectively. Learning Tools developed were categorized as practical with the practicality of teachers and students being $80 \%$ and $86.03 \%$. The learning tools developed were effective in increasing students' competencies with classical completeness for cognitive, affective, and psychomotor competencies for $89.66 \%, 100 \%$, and $100 \%$ respectively. Thus, it can be concluded that the developed practicum-based learning tool was a valid, practical, and effective learning tool.
\end{abstract}

Keywords: Learning Tools; Practicum of Inquiry; Electrical Circuits Analysis.

Copyright (c) 2020 Candra et al This is an open access article under the $\mathrm{CC}-\mathrm{BY}$ license Praktikum Inkuiri Untuk Mata Pelajaran Menganalisis Rangkaian Listrik. JINoP (Jurnal Inovasi Pembelajaran), 6(1). doi:https://doi.org/10.22219/jinop.v6i1.11756 


\section{PENDAHULUAN}

Proses pembelajaran pada setiap satuan pendidikan dasar dan menengah harus interaktif, inspiratif, menyenangkan, menantang, dan memotivasi peserta didik untuk berpartisipasi aktif, serta memberikan ruang yang cukup bagi prakarsa, kreativitas, dan kemandirian sesuai dengan bakat, minat, dan perkembangan fisik serta psikologis peserta $\operatorname{didik(Hsu,~et~al.,~2017;~Kant,~Scheiter,~\& ~Oschatz,~2017;~Candra~et~al.,~2019).~Guru~}$ diharapkan dapat merencanakan pembelajaran melalui penyusunan perangkat pembelajaran seperti Rencana Pelaksanaan Pembelajaran (RPP) dan alat kelengkapan pembelajaran seperti Lembar Kegiatan Siswa (LKS) serta media pembelajaran. Perangkat pembelajaran disusun disesuaikan dengan model pembelajaran yang digunakan oleh guru dan dianggap paling efektif digunakan dalam mencapai tujuan pembelajaran serta disesuaikan dengan karakteristik peserta didik.

Mata pelajaran Menganalisis Rangkaian Listrik (MRL) merupakan salah satu kelompok mata pelajaran dasar kompetensi kejuruan kompetensi keahlian Teknik Distribusi Tenaga Listrik (TDTL) di SMKN 1 Padang. Mata pelajaran MRL dengan salah satu materi Rangkaian Kemagnetan. Proses belajar mata pelajaran ini tidak cukup hanya dengan menghafalkan konsep dan fakta yang sudah ada, akan tetapi peserta didik diharapkan dapat menemukan dan menerapkan konsep-konsep tersebut melalui kegiatan observasi dan eksperimen. Peserta didik diharapkan tidak hanya menguasai konsep tetapi juga memiliki keterampilan dalam melakukan kegiatan praktikum MRL (Yanto et al., 2019).

Upaya-upaya yang dilakukan dalam mengembangkan kemampuan siswa untuk menguasai konsep dan melakukan praktikum MRL, telah dilakukan wawancara terhadap guru dan siswa serta pengamatan terhadap proses pembelajaran dan perangkat pembelajaran MRL bagi siswa kelas X TDTL di SMKN 1 Padang. Dari pengamatan yang dilakukan terhadap perangkat pembelajaran yang dibuat oleh guru mata pelajaran MRL di SMKN 1 Padang terlihat bahwa format RPP yang digunakan belum sesuai dengan format RPP terbaru.

Kegiatan pembelajaran yang ada dalam Rencana Pelaksanaan Pembelajaran (RPP) lebih menekankan kepada kemampuan berfikir (kognitif) siswa. Model pembelajaran yang digunakan umumnya sama yaitu model pembelajaran tradisional dengan metode ceramah dan diskusi sehingga pembelajaran yang dirancang masih berpusat pada guru dan tidak memberikan pengalaman yang kongkrit bagi peserta didik. Belum terdapat Lembar Kegiatan Siswa (LKS) sebagai panduan saat siswa melaksanakan kegiatan praktikum, sehingga tugas-tugas yang diberikan guru kepada siswa di tuliskan dipapan tulis. Siswa akan mengalami kesulitan dalam melaksanakan proses pembelajaran apabila tidak dilengkapi dengan media atau petunjuk pelaksanaan pembelajaran (Eliza et al., 2019). Untuk itu perlu dikembangkan LKS menggunakan model pembelajaran berbasis praktikum inkuiri yang didalamnya memuat sejumlah pertanyaan untuk menggiring siswa melaksanakan kegiatan praktikum dan menemukan konsep pembelajaran yang dipelajari (Hong et al., 2019).

Kegiatan praktikum MRL tidak dilaksanakan di satu laboratorium khusus, dilaksanakan setelah pemberian materi teori di kelas dan bersifat verifikasi tidak menekankan pada proses perolehan pengetahuan melalui metode inkuiri. Kegiatan praktikum dilaksanakan secara berkelompok. Jumlah siswa dalam satu kelompok tergantung pada jumlah peralatan yang tersedia. Siswa melaksanakan kegiatan praktikum berdasarkan uraian secara rinci oleh guru di depan kelas dan format tabel pengamatan praktikum di tulis oleh guru di papan tulis. Guru membimbing siswa pada

Oriza Candra, UsImeldi, Doni Tri Putra Yanto, Femypadillah Ismanto, Pengembangan Perangkat Pembelajaran Berbasis Praktikum Inkuiri Untuk Mata Pelajaranmenganalisis Rangkaian Listrik 
setiap langkah kegiatan praktikum. Guru MRL menyatakan bahwa kemampuan siswa dalam menguasai konsep MRL masih rendah atau berada dibawah Kriteria Ketuntasan Minimal (KKM). Hal ini bisa dilihat pada tabel 1.

Tabel 1. Ketuntasan Belajar Siswa Kelas X TDTL Tahun 2017/2018 pada Ujian Mid Semester 1 untuk Mata Pelajaran MRL

\begin{tabular}{lllll}
\hline \multirow{2}{*}{ Nilai } & \multicolumn{4}{l}{ Ketuntasan Belajar Siswa Kelas X } \\
& X TDTL-A & $\mathbf{( \% )}$ & X TDTL-B & $(\%)$ \\
\hline$\geq$ B & 7 & 25 & 6 & 20.7 \\
$<$ B & 21 & 75 & 23 & 79.3 \\
Jumlah & 28 & 100 & 29 & 100 \\
\hline
\end{tabular}

Sumber: Asril, Buku Nilai MRL di SMK N 1 Padang

Rendahnya hasil pembelajaran peserta didik salah satunya disebabkan oleh model pembelajaran yang digunakan kurang menunjang kegiatan pembelajaran dalam mencapai tujuan pembelajaran MRL. Candra et al.(2020)mengungkapkan bahwa siswa setuju materi pelajaran lebih lama teringat dengan menganalisis permasalahan nyata yang berhubungan dengan materi tersebut. Menganalisis permasalahan secara nyata salah satunya dapat dilakukan melalui kegiatan praktikum di laboratorium. Metode pembelajaran seperti ini disebut metode pembelajaran eksperimen. Selain metode eksperimen, salah satu metode pembelajaran yang dianggap sesuai dan dapat mendukung penanaman pemahaman konsep siswa secara mendalam yaitu metode pembelajaran inkuiri (Elfizon, Syamsuarnis, \& Candra, 2017; McNew-Birren \& van den Kieboom, 2017).

Penerapan metode pembelajaran inkuiri telah dilakukan oleh beberapa peneliti sebelumnya seperti Thuneberg et al. (2018) yang menerapkan metode pembelajaran inkuiri pada proses pembelajaran fisika. Suárez et al (2018) mengembangkan bahan ajar berbasis mobile dengan menerapkan metode inkuiri. Andrews-Larson et al. (2019) dan Jiang et al.(2018) yang meneliti tentang penerapan metode pembelajaran inkuri pada proses pembelajaran praktik. Semua hasil penelitian yang dilakukan oleh peneliti tersebut menunjukan bahwa metode pembelajaran inkuiri berpengaruh positif terhadap peningkatan hasil belajar peserta didik terutama untuk materi pembelajaran yang bersifat analisis praktis. Namun, pada penelitian tersebut tidak dilakukan pada kedua bentuk proses pembelajaran yaitu teori dan praktik. Penelitian masih dilakukan pada masingmasing satu jenis proses pembelajaran. Pada penelitian ini dilakukan pengembangan perangkat pembelajaran menggunakan metode inkuiri dan menggabungkan antara pembelajaran teori dan praktik. Pada pelaksanaanya proses pembelajaran akan menggunakan metode pembelajaran berbasis inkuiri pada pembelajaran teori maupun praktik dengan tujuan dapat meningkatkan kemampuan analisis peserta didik, memotivasi peserta didik untuk berperan aktif dalam proses pembelajaran, serta meningkatkan hasil belajar akhir peserta didik atau siswa.

Thuneberg et al. (2018) mengemukakan, metode pembelajaran yang dapat mendukung standar proses pendidikan adalah: a) pembelajaran berorientasi aktivitas siswa, b) pembelajaran ekspositori, c) pembelajaran inkuiri, d) pembelajaran berbasis masalah, e) pembelajaran peningkatan kemampuan berfikir, f) pembelajaran kooperatif, g) pembelajaran kontekstual, h) pembelajaran afektif. Pembelajaran inkuiri dapat mendukung standar proses pendidikan dalam hal ini yaitu dapat meningkatkan kualitas pembelajaran. Melalui pembelajaran dengan metode inkuiri siswa diharapkan dapat 
menemukan dan mengkonstruksi sendiri pengetahuannya. Pada metode pembelajaran inkuiri siswa melakukan kegiatan yang mencakup observasi, mengumpulkan data, menganalisis data, menginterpretasikan data, dan mengkomunikasikan hasil. Semua kegiatan tersebut juga dilakukan pada metode pembelajaran eksperimen.

Metode inkuiri dan pemecahan masalah tidaklah berbeda (Hong et al., 2019). Pembelajaran menggunakan metode inkuiri dapat mengembangkan keterampilan dalam memecahkan masalah. Pada metode pembelajaran inkuiri dan eksperimen dapat dikembangkan keterampilan siswa dalam memecahkan masalah yang berkaitan dengan konsep pembelajaran yang sedang dipelajari. Metode pembelajaran yang digunakan pada model pembelajaran berbasis praktikum inkuiri yaitu inkuiri, eksperimen, dan pemecahan masalah. Berbagai studi menyimpulkan bahwa metode inkuri lebih efektif secara signifikan dalam meningkatkan keterampilan berfikir (Hong et al., 2019; Theobald \& Ramsbotham, 2019; Thuneberg et al., 2018).

Model pembelajaran yang dapat digunakan untuk meningkatkan kemampuan siswa dalam menguasai konsep MRL dan melakukan praktikum MRL salah satunya adalah model pembelajaran berbasis praktikum inkuiri. Model pembelajaran berbasis praktikum inkuiri hanya dapat dilaksanakan pada mata pelajaran yang membutuhkan pemahaman konsep yang mendalam melalui kegiatan praktikum (Hong et al., 2019). Mata pelajaran MRL dengan materi Rangkaian Kemagnetan erat kaitannya dengan model pembelajaran berbasis praktikum inkuiri. Pada materi ini dapat ditunjukkan apa yang dimaksud dengan magnet, medan magnet, dan induksi elektromagnetik. Siswa juga dapat menemukan dan menerapkan hukum-hukum dasar pada rangkaian kemagnetan, prinsip kerja motor listrik dan generator listrik dari permasalahan yang diberikan. Penyajian kepada situasi masalah yang autentik dan bermakna diharapkan dapat memberikan motivasi kepada siswa untuk melakukan penyelidikan untuk menemukan konsep dari materi yang dipelajari.

Penjelasan dan permasalahan tersebut menjadi latar belakang dilakukan penelitian untuk mengembangkan perangkat pembelajaran berbasis praktikum inkuiri pada mata pelajaran MRL. Perangkat pembelajaran yang dikembangkan ini diharapkan dapat meningkatkan kemampuan siswa sesuai dengan kelebihan-kelebihan yang dimiliki oleh metode pembelajaran tersebut. Kelebihan yang diharapkan terjadi pada proses pembelajaran MRL adalah siswa memiliki kemampuan yang baik dalam menguasai konsep MRL, memiliki keterampilan melakukan praktikum, dan mampu menerapkan konsep MRL ke dalam mata pelajaran lainnya yang berhubungan dengan konsep MRL.

\section{METODE}

Penelitian ini merupakan penelitian dan pengembangan (research and development). Dalam penelitian ini dikembangkan produk berupa perangkat pembelajaran berbasis praktikum inkuiri pada mata pelajaran Menganalisis Rangkaian Listrik (MRL). Melalui penerapan perangkat pembelajaran yang dikembangkan ini diharapkan kompetensi siswa pada mata pelajaran tersebut dapat meningkat.

Model pengembangan perangkat pembelajaran yang digunakan adalah model pengembangan perangkat pembelajaran Thiagarajan dan Semmel (Trianto, 2010) yaitu Model 4-D. Model pengembangan 4-D ini terdiri atas 4 tahap pengembangan, meliputi tahap pendefinisian (define), tahap perancangan (design), tahap pengembangan (develop), dan tahap penyebaran (desseminate) (Sugiyono, 2018). Pada penelitian ini hanya dilakukan 3 tahap yaitu tahap pendefinisian, tahap perancangan, dan tahap pengembangan. Untuk tahap penyebaran tidak dilakukan karena memerlukan waktu yang

Oriza Candra, UsImeldi, Doni Tri Putra Yanto, Femypadillah Ismanto, Pengembangan Perangkat Pembelajaran Berbasis Praktikum Inkuiri Untuk Mata Pelajaranmenganalisis Rangkaian Listrik 
terlalu lama dan memerlukan jumlah sampel yang banyak (Sukardi, et al., 2017; Dobber, et al., 2017).

Jenis data yang dihasilkan pada penelitian ini adalah data primer. Data pertama berupa hasil validasi perangkat pembelajaran yang diberikan oleh validator, data kedua berupa hasil angket praktikalitas perangkat pembelajaran yang bersumber dari guru dan siswa, dan data ketiga adalah data keefektifan produk yang didapatkan dari hasil tes penguasaan konsep (pengetahuan) dan penilaian proses pembelajaran selama penerapan perangkat pembelajaran yang dikembangkan.

Teknik pengumpulan data pada penelitian ini dibagi menjadi tiga yaitu pengambilan data validitas, praktikalitas, dan efektifitas. Pengumpulan data validitas dilakukan dengan menggunakan angket validitas yang diberikan kepada ahli sesuai dengan bidang yang divalidasi. Pengumpulan data praktikalitas dilakukan dengan menggunakan angket praktikalitas yang diberikan kepada guru dan siswa setelah menerapkan perangkat pembelajaran yang dikembangkan pada proses pembelajaran. Sedangkan, data efektifitas didapatkan dengan menggunakan instrumen berupa tes objektif untuk mengukur hasil belajar siswa.

Teknik analisis data yang digunakan juga disesuaikan dengan jenis data yang didapatkan. Teknik analisis data dibagi menjadi tiga yakni analisis validitas, analisis praktikalitas, dan analisis efektifitas. Data validitas dan praktikalitas dianalisis dengan teknik analisis presentase yang dikemukan oleh Riduwan(2010) berikut:

$$
\text { Nilai dalam } \%=\frac{\text { Nilai total }}{\text { Nilai Maksimum }} \text { X } 100 \%
$$

Data efektifitas dianalisis dengan analisis ketercapaian KKM klasikal siswa setelah mengikuti proses pembelajaran MRL seperti analisis yang dilakukan oleh Yanto et al. (2017) dan Baird (2018). Berdasarkan kurikulum dan analisis Kriteria Ketuntasan Minimal (KKM), maka nilai KKM untuk mata pelajaran MRL adalah 80. Apabila siswa yang hasil belajar akhirnya berada di atas nilai KKM sebanyak $\geq 80 \%$ maka perangkat pembelajaran yang dikembangkan efektif digunakan pada proses pembelajaran MRL.

\section{HASIL DAN PEMBAHASAN}

Penelitian ini menghasilkan produk berupa perangkat pembelajaran yaitu, Rencana Pelaksanaan Pembelajaran (RPP) dan Lembar Kegiatan Siswa (LKS) yang dirancang menggunakan model pembelajaran berbasis praktikum inkuiri pada mata pelajaran Menganalisis Rangkaian Listrik (MRL) dengan materi Rangkaian Kemagnetan untuk siswa kelas X TDTL-B di SMKN 1 Padang. Prosedur yang ditempuh dalam mengembangkan perangkat pembelajaran ini meliputi tahap pendefinisian, tahap perancangan, dan tahap pengembangan.

\section{Tahap Pendefinisian}

a. Analisis Kurikulum

Kurikulum SMK berisi mata pelajaran wajib, mata pelajaran kejuruan, muatan lokal, dan pengembangan diri. Dasar Kompetensi Kejuruan, dan Kompetensi Kejuruan. Dasar Kompetensi Kejuruan terdiri dari berbagai mata pelajaran yang ditentukan sesuai dengan kebutuhan setiap program keahlian. Salah satu mata pelajaran Dasar Kompetensi Kejuruan yang sangat penting dikuasai oleh siswa TDTL karena sangat erat kaitannya dengan beberapa mata pelajaran pada Kompetensi Kejuruan yaitu mata pelajaran Menganalisis Rangkaian Listrik (MRL). 
Proses untuk Satuan Pendidikan Dasar dan Menengah siswa dituntut utuk dapat menguasai setiap kompetensi program keahlian, sedangkan guru dituntut untuk dapat merencanakan, melaksanakan, dan mengevaluasi pembelajaran. Oleh karena itu guru perlu merencanakan pembelajaran melalui penyusunan perangkat pembelajaran yang dapat membantu siswa dalam menguasai setiap kompetensi program keahlian. Perangkat pembelajaran dikembangkan tidak hanya berpusat pada guru melainkan harus interaktif, inspiratif, menyenangkan, menantang, dan memotivasi peserta didik untuk berpartisipasi aktif, serta memberikan ruang yang cukup bagi prakarsa, kreativitas, dan kemandirian sesuai dengan bakat, minat, dan perkembangan fisik serta psikologis peserta didik (Elfizon, dkk. 2017).

\section{b. Analisis Siswa}

Siswa kelas X TDTL SMKN 1 Padang tahun ajaran 2014/2015 terdiri atas dua kelas yang berjumalah 57 orang. Berdasarkan data yang diperoleh dari sekolah siswa berusia 16-17 tahun. Siswa berpendapat bahwa pembelajaran dengan model pembelajaran praktikum lebih menyenangkan jika dibandingkan dengan pembelajaran teori. Salah satu model pembelajaran yang dapat mengembangkan kemampuan berpikir siswa adalah model pembelajaran berbasis praktikum inkuiri.

\section{c. Analisis Konsep}

Konsep-konsep utama yang akan dipelajari oleh siswa disusun secara sistematis sesuai dengan perangkat pembelajaran yang akan dikembangkan. Perangkat pembelajaran yang akan dikembangkan adalah perangkat pembelajaran Menganalisis Rangkaian Listrik.

\section{d. Analisis Tugas}

Analisis tugas mencakup analisis struktur isi, yang terdiri dari analisis tugas untuk pancapaian kompetensi kognitif, kompetensi psikomotor, dan kompetensi afektif.

\section{e. Perumusan Tujuan Pembelajaran}

Setelah keempat analisis di atas dilakukan kemudian dirumuskan tujuan pembelajaran untuk mata pelajaran MRL dengan materi rangkaian kemagnetan. Tujuan pembelajaran adalah pernyataan tentang hasil pembelajaran apa yang diharapkan.

\section{Tahap Perancangan}

Berdasarkan hasil analisis pada tahap pendefenisian dilakukan perancangan prototipe perangkat pembelajaran Menganalisis Rangkaian Listrik (MRL) menggunakan model pembelajaran berbasis praktikum inkuiri dengan materi Rangkaian Kemagnetan. Perangkat pembelajaran yang dikembangkan terdiri dari:

\section{a. Rencana Pelaksanaan Pembelajaran}

Rencana Pelaksanaan Pembelajaran dirancang dengan memperhatikan prinsip pengembangan RPP dan langkah-langkah pengembangan RPP. Komponen pada RPP yang dikembangkan terdiri atas 13 poin.

\section{b. Lembar Kegiatan Siswa}

LKS yang dikembangkan berisi sejumlah pertanyaan yang merupakan masalahmasalah yang berkaitan dengan konsep pembelajaran yang akan dipelajari untuk

Oriza Candra, Uslmeldi, Doni Tri Putra Yanto, Femypadillah Ismanto, Pengembangan Perangkat Pembelajaran Berbasis Praktikum Inkuiri Untuk Mata Pelajaranmenganalisis Rangkaian Listrik 
mengajak siswa berpikir dengan permasalahan secara nyata dan mengembangkan keterampilan berpikir ilmiah siswa. Pertanyaan-pertanyaan yang diberikan menggiring siswa untuk melakukan kegiatan praktikum guna memecahkan permasalahan yang diberikan dan menemukan konsep pembelajaran yang akan dipelajari, seperti pada gambar 1 dapat dilihat salah satu contoh lembaran LKS.

Selain merancang perangkat pembelajaran, pada tahap perancangan juga dikembangkan instrumen penelitian untuk mengumpulkan data penelitian. Instrumen penelitian mencakup instrumen validitas, praktikalitas, dan efektifitas. Instrumen validitas perangkat pembelajaran terdiri atas Lembar Validasi RPP dan Lembar Validasi LKS. Instrumen praktikalitas terdiri atas Angket Kepraktisan Perangkat Pembelajaran oleh Guru dan Angket Kepraktisan Perangkat Pembelajaran oleh Siswa. Instrumen keefektifan produk terdiri atas tes penguasaan konsep berupa tes esai (posttest) yang valid dan reliable, lembar pengamatan sikap, dan lembar penilaian kinerja (Hamdani, Yanto, \& Maulana, 2019).

\section{Tahap Pengembangan}

Rancangan perangkat pembelajaran dinilai oleh validator lewat lembar validasi, hasil penilaian dari validator dianalisis dan dilakukan perbaikan sesuai dengan saran yang diberikan oleh validator, sehingga didapatkan perangkat pembelajaran yang valid. Berikut disajikan analisis data dari tahap pengembangan.

a. Hasil Validitas Perangkat Pembelajaran

Berdasarkan hasil validitas perangkat pembelajaran oleh validator diperoleh data seperti tabel 2 .

Tabel 2. Hasil Validitas Perangkat Pembelajaran

\begin{tabular}{|c|c|c|c|c|c|c|}
\hline \multirow[t]{2}{*}{ No. } & \multirow[t]{2}{*}{ Perangkat Pembelajaran } & \multicolumn{3}{|c|}{$\begin{array}{l}\text { \%Rata-rataPenilaian } \\
\text { dari validator }\end{array}$} & \multirow[t]{2}{*}{ Jumlah } & \multirow[t]{2}{*}{ Rata-rata } \\
\hline & & I & II & III & & \\
\hline 1. & $\begin{array}{l}\text { RencanaPelaksanaan } \\
\text { Pembelajaran }\end{array}$ & 95.83 & 70.83 & 89.58 & 256.25 & 85.42 \\
\hline 2. & LembarKegiatan Siswa & 95.83 & 79.17 & 87.50 & 262.50 & 87.50 \\
\hline
\end{tabular}

Dari hasil validitas Rencana Pelaksanaan Pembelajaran (RPP) dan Lembar Kegiatan Siswa (LKS) pada tabel 2 secara keseluruhan perangkat pembelajaran yang dikembangkan berupa RPP dan LKS telah dapat dikategorikan valid. Berdasarkan rekapitulasi penilaian validitas perangkat pembelajaran, maka dilakukan pengelompokkan berdasarkan aspek.

1) Rencana Pelaksanaan Pembelajaran

Pengelompokan aspek penilaian untuk validitas pengembangan Rencana Pelaksanaan Pembelajaran (RPP) dapat dilihat pada tabel 3.

Tabel 3. Hasil Validitas Pengembangan RPP

\begin{tabular}{clc}
\hline \multicolumn{1}{c}{ Pengelompokan Aspek Penilaian } & \% Rata-rata \\
\hline 1. & Syarat Didaktik & 84.38 \\
2. & Syarat Konstruksi & 83.33 \\
3. & Syarat Teknis & 91.67 \\
& Rata-rata & 86.46 \\
\hline
\end{tabular}


Dari pengelompokkan aspek penilaian untuk validitas RPP pada tabel 3 dapat dilihat bahwa syarat didaktik dan syarat konstruksi dikategorikan valid sedangkan syarat teknis dikategorikan sangat valid. Secara keseluruhan RPP yang dikembangkan telah dapat dikategorikan valid.

2) Lembar Kegiatan Siswa

Pengelompokkan aspek penilaian untuk validitas pengembangan Lembar Kegiatan Siswa (LKS) dapat dilihat bahwa syarat didaktik dikategorikan sangat valid, sedangkan syarat konstruksi dan syarat teknis dikategorikan valid. Secara keseluruhan LKS yang dikembangkan telah dapat dikategorikan valid seperti pada tabel 4.

Tabel 4. Hasil Validitas Pengembangan LKS

\begin{tabular}{clc}
\hline No. & \multicolumn{1}{c}{ Pengelompokan Aspek Penilaian } & \% Rata-rata \\
\hline 1. & Syarat Didaktik & 94.44 \\
2. & Syarat Konstruksi & 85.71 \\
3. & Syarat Teknis & 83.33 \\
& Rata-rata & 87.83 \\
\hline
\end{tabular}

b. Hasil Praktikalitas Perangkat Pembelajaran

1) Berdasarkan angket guru

Angket yang diberikan pada guru bertujuan untuk melihat kepraktisan perangkat pembelajaran berbasis praktikum inkuiri. Berdasarkan hasil pengisian angket kepraktisan perangkat pembelajaran oleh guru diperoleh data tentang kepraktisan perangkat pembelajaran berbasis praktikum inkuiri dengan materi rangkaian kemagnetan seperti pada tabel 5 .

Tabel 5. Kepraktisan Perangkat Pembelajaran Berdasarkan Angket Guru di SMKN 1 Padang

\begin{tabular}{|c|c|c|}
\hline No. & Aspek Yang Dinilai & Persentase Penilaian \\
\hline 1 & Daya tarik & $80 \%$ \\
\hline 2 & Proses pengembangan & $80 \%$ \\
\hline 3 & Kemudahan penggunaan & $90 \%$ \\
\hline 4 & Keberfungsian dan kegunaan & $80 \%$ \\
\hline 5 & Variatif & $90 \%$ \\
\hline 6 & \multirow[t]{2}{*}{ Nilai ekonomis } & $60 \%$ \\
\hline & & $80 \%$ \\
\hline
\end{tabular}

Dari hasil penilaian melalui angket kepraktisan perangkat pembelajaran oleh guru di SMKN 1 Padang pada tabel 5 dapat dilihat bahwa untuk setiap aspek yang dinilai berupa daya tarik, proses pengembangan, keberfungsian dan kegunaan dikategorikan praktis. Untuk aspek kemudahan penggunaan dan variatif dikategorikan sangat praktis. 2) Berdasarkan angket dari siswa

Angket yang diberikan kepada siswa bertujuan untuk melihat kepraktisan perangkat pembelajaran berbasis praktikum inkuiri. Berdasarkan hasil pengisian angket kepraktisan perangkat pembelajaran oleh siswa diperoleh data tentang kepraktisan perangkat pembelajaran dengan materi rangkaian kemagnetan seperti pada tabel 6.

Oriza Candra, Uslmeldi, Doni Tri Putra Yanto, Femypadillah Ismanto, Pengembangan Perangkat Pembelajaran Berbasis Praktikum Inkuiri Untuk Mata Pelajaranmenganalisis Rangkaian Listrik 
Tabel 6. Kepraktisan Perangkat Pembelajaran Berdasarkan Angket Siswa di SMKN 1 Padang.

\begin{tabular}{clc}
\hline No. & \multicolumn{1}{c}{ Aspek Yang Dinilai } & Persentase Penilaian \\
\hline 1 & Ketertarikan siswa & $84.74 \%$ \\
2 & Kemudahan penggunaan & $87.31 \%$ \\
3 & Kemungkinan peningkatan aktivitas Siswa & $86.62 \%$ \\
4 & Ketersediaan waktu yang cukup & $86.55 \%$ \\
& Rata-rata & $86.31 \%$
\end{tabular}

Dari hasil penilaian melalui angket kepraktisan perangkat pembelajaran oleh siswa di SMKN 1 Padang pada tabel 6 dapat dilihat bahwa untuk setiap aspek yang dinilai berupa ketertarikan siswa, kemudahan penggunaan, kemungkinan peningkatan aktivitas siswa, dan ketersediaan waktu yang cukup dalam penerapan perangkat pembelajaran berbasis praktikum inkuiri dengan materi rangkaian kemagnetan dikategorikan praktis. Secara keseluruhan berdasarkan angket yang diberikan kepada siswa di SMKN 1 Padang perangkat pembelajaran berbasis praktikum inkuiri dengan materi rangkaian kemagnetan telah dapat dikategorikan praktis.

\section{c. Hasil Efektivitas Perangkat Pembelajaran}

Perangkat pembelajaran yang telah valid diujicobakan terbatas pada kelas X TDTLB di SMKN 1 Padang. Efektivitas perangkat pembelajaran berbasis praktikum inkuiri diproleh dari ketuntasan hasil belajar siswa setelah menggunakan perangkat pembelajaran berbasis praktikum inkuiri di kelas. Hasil belajar didapatkan dari tes penguasaan konsep siswa berupa tes esai (posttest) untuk kompetensi kognitif, lembar penilaian kinerja untuk kompetensi psikomotor, dan lembar penilaian sikap untuk kompetensi afektif. Siswa kelas X TDTL-B di SMKN 1 Padang terdiri atas 29 siswa.

Tabel 7. Ketuntasan Siswa kelas X TDTL-B di SMKN 1 Padang

\begin{tabular}{ccccc}
\hline Kompetensi & \multicolumn{2}{c}{ Tuntas } & Siswa & Persentase \\
\cline { 2 - 5 } & Siswa & Persentase & 3 Siswa & $10.34 \%$ \\
Kognitif & 26 Siswa & $89.66 \%$ & 0 Siswa & $0 \%$ \\
Psikomotor & 29 Siswa & $100 \%$ & 0 Siswa & $0 \%$ \\
Afektif & 29 Siswa & $100 \%$ & 0 \\
\hline
\end{tabular}

Tabel 7 di atas menjelaskan lebih dari $85 \%$ siswa dikatakan tuntas atau memiliki nilai di atas KKM yaitu 80 untuk kompetensi kognitif, untuk kompetensi psikomotor dari hasil lembar penilaian kinerja sebanyak 29 siswa mendapatkan nilai $\geq 80$. Ketuntasan klasikal siswa yang diperoleh yaitu $100 \%$. Hal ini berarti bahwa lebih dari $85 \%$ siswa dikatakan tuntas atau memiliki nilai di atas KKM yaitu 80 untuk kompetensi psikomotor. Kompetensi afektif dari hasil lembar penilaian kinerja sebanyak 29 siswa mendapatkan nilai $\geq$ B (kategori memuaskan). Ketuntasan klasikal siswa yang diperoleh yaitu $100 \%$. Ha ini berarti bahwa lebih dari $85 \%$ siswa dikatakan tuntas atau memiliki nilai di atas KKM yaitu B (kategori memuaskan) untuk kompetensi afektif.

Perangkat pembelajaran dikembangkan menggunakan model pembelajaran berbasis praktikum inkuiri pada mata pelajaran Menganalisis Rangkaian Listrik (MRL) untuk siswa kelas X TDTL di SMKN 1 Padang. Perangkat pembelajaran dikembangkan pada materi Rangkaian Kemagnetan yang terdiri atas RPP dan LKS. Model pembelajaran berbasis praktikum inkuiri yaitu model pembelajaran yang mengintegrasikan kegiatan praktikum dan pembelajaran teori. Hal ini sesuai dengan hasil penelitian bahwa proses 
pembelajaran yang paling baik adalah pembelajaran yang tidak memisahkan teori dan praktikum tetapi mengintegrasikan keduanya (Hong et al., 2019).

Perangkat pembelajaran berbasis praktikum inkuiri yang dikembangkan telah melalui tahap uji validitas, praktikalitas, dan efektivitas. Menurut Sukardi et al., (2017) validitas menunjukkan tingkat kesahihan, yaitu mengukur apa yang seharusnya diukur. Validitas yang dilakukan pada penelitian ini terdiri atas validitas isi dan validitas konstruk. Untuk menentukan validitas isi diperlukan adanya ahli bidang studi, ahli pengukuran, dan para pakar yang memiliki keahlian yang relevan dengan bidang kajiannya (Sukardi et al., 2017). Sedangkan untuk menguji validitas konstruksi dapat digunakan pendapat para ahli (Riduwan, 2010). Dari hasil uji validitas yang dilakukan dapat disimpulkan bahwa perangkat pembelajaran berbasis praktikum inkuiri ini valid untuk digunakan sebagai salah satu perangkat pembelajaran pada mata pelajaran MRL.

Uji praktikalitas dilakukan dengan meminta tanggapan melalui angket kepraktisan perangkat pembelajaran yang meliputi angket respon guru dan respon siswa. Dari hasil uji praktikalitas yang dilakukan dapat disimpulkan bahwa perangkat pembelajaran berbasis praktikum inkuiri yang dikembangkan ini praktis untuk digunakan sebagai salah satu perangkat pembelajaran pada mata pelajaran MRL. Hal ini sesuai dengan yang diungkapkan oleh Arikunto (2008) dan Rolim et al. (2019) bahwa sebuah produk dikatakan memiliki praktikailitas yang tinggi apabila produk tersebut bersifat praktis, mudah pengadministrasiannya.

Uji efektivitas dilakukan dengan cara melihat ketuntasan klasikal siswa pada kompetensi dasar menganalisis rangkaian kemagnetan yang diperoleh melalui tes penguasaan konsep berupa tes esai (posttest) untuk kompetensi kognitif dan pengamatan selama proses pembelajaran untuk kompetensi psikomotor dan afektif. Hal ini sesuai dengan yang diungkapkan oleh Takeuchi et al., (2018) dan (Teig et al. (2018) bahwa keefektifan pembelajaran biasanya diukur dengan tingkat pencapaian hasil belajar. Dari hasil uji efektivitas untuk setiap kompetensi kognitif, psikomotor dan afektif tersebut dapat disimpulkan bahwa perangkat pembelajaran berbasis praktikum inkuiri yang dikembangkan efektif untuk digunakan sebagai salah satu perangkat pembelajaran pada mata pelajaran MRL. Hal ini sesuai dengan hasil penelitian sebelumnya yang dilakukan oleh beberapa peneliti seperti Andrews-Larson et al. (2019); Hong et al. (2019); Zhang(2019), dan Cleovoulou \& Beach (2019) bahwa terjadi peningkatan aktivitas dan hasil belajar siswa dengan menggunakan metode inkuiri pada proses pembelajaran teori dan praktik.

Pada penelitian ini, perangkat pembelajaran berbasis praktikum inkuiri dikembangkan tidak hanya untuk proses pembelajaran teori atau praktik saja seperti beberapa penelitian yang dilakukan oleh para peneliti sebelumnya yaitu Andrews-Larson et al. (2019); Hong et al. (2019); Zhang (2019), dan Cleovoulou \& Beach (2019) yang mengembangkan perangkat pembelajaran berbasis inkuiri pada pembelajaran teori atau praktik saja secara terpisah. Namun, penelitian ini mengembangkan perangkat pembelajaran berbasis praktikum inkuiri untuk proses pembelajaran gabungan antara teori dan praktik, sehingga keunggulan pada penelitian ini adalah menghasilkan perangkat pembelajaran berbasis praktikum yang dapat diterapkan pada proses pembelajaran yang menggabungkan pembelajaran teori dan praktik yaitu mata pelajaran Menganalis Rangkaian Listrik. Penerapan dan pengujian pada proses pembelajaran yang menggabungkan antara teori dan praktik tersebut akan akan memperkaya hasil pengujian validitas, praktikalitas dan efektifitas dari perangkat pembelajaran yang dikembangkan. Penelitian ini dapat dilanjutkan dengan melakukan uji coba skala besar untuk menambah

Oriza Candra, UsImeldi, Doni Tri Putra Yanto, Femypadillah Ismanto, Pengembangan Perangkat Pembelajaran Berbasis Praktikum Inkuiri Untuk Mata Pelajaranmenganalisis Rangkaian Listrik 
hasil analisis praktikalitas dan efektifitas perangkat pembelajaran yang dikembangkan. Ujicoba skala besar dapat dilanjutkan dengan ujicoba pada kelas lain selain objek penelitian pada mata pelajaran dan sekolah yang sama. Namun, juga dapat dilakukan pada siswa dengan tingkat kelas dan mata pelajaran yang sama namun pada sekolah yang berbeda. pengujian lebih lanjut ini akan semakin memperkuat hasil penelitian tentang praktikalitas dan efektifitas perangkat pembelajaran berbasis inkuiri pada proses pembelajaran MRL siswa program studi Teknik Instalasi Tenaga Listrik.

\section{SIMPULAN}

Hasil kegiatan pengujian, pengukuran dan analisis data yang dilakukan menunjukkan bahwa perangkat pembelajaran berbasis praktikum inkuiri yang dikembangkan telah memenuhi kriteria sebagai perangkat pembelajaran yang dapat diterapkan pada proses pembelajaran. Hal ini diindikasikan dengan hasil analisis yang membuktikan bahwa perangkat pembelajaran yang dikembangkan telah valid, praktis, dan efektif. Selain itu, perangkat pembelajaran yang dikembangkan juga dapat meningkatkan hasil belajar siswa pada mata pelajaran MRL yang diindikasikan dengan hasil belajar siswa yang mengalami peningkatan yang signifikan setelah penerapan perangkat pembelajaran berbasis praktikum inkuiri. Dengan demikian, maka dapat disimpulkan bahwa perangkat pembelajaran berbasis praktikum inkuiri telah valid, praktis dan efektif digunakan pada proses pembelajaran MRL dan perangkat pembelajaran tersebut juga mampu meningkatkan hasil belajar siswa sehingga pelaksanaan pembelajaran dapat semakin optimal.

\section{DAFTAR PUSTAKA}

Andrews-Larson, C., McCrackin, S., \& Kasper, V. (2019). The next time around: scaffolding and shifts in argumentation in initial and subsequent implementations of inquiry-oriented instructional materials. Journal of Mathematical Behavior, 56(June), 100719. https://doi.org/10.1016/j.jmathb.2019.100719

Arikunto, S. (2008). Dasar-Dasar Evaluasi Pendidikan (Edisi Revisi). Jakarta: Bumi Aksara.

Baird, K. M., Saito, A. S., Eustace, J., \& Creedy, D. K. (2018). Effectiveness of training to promote routine enquiry for domestic violence by midwives and nurses: A prepost evaluation study. Women and Birth, 31(4), 285-291. https://doi.org/10.1016/j.wombi.2017.10.014

Candra, O., Dewi, C., Yanto, D. T. P., \& Hastuti, H. (2020). The Implementation of Power Electronics Training to Enhance Student Learning Activities in the Power Electronics Learning Process. International Journal of Innovation, Creativity and Change, 11(4), 362-373. Retrieved from https://www.ijicc.net/index.php/ijicceditions/2020/155-vol-11-iss-4

Candra, O., Pulungan, A. B., Eliza, F., Elfizon, \& Syamsuarnis. (2019). Development of Miniature Secondary Network of Electric Power Distribution System as a Learning Media for Electrical Engineering Students. Journal of Physics: Conference Series, 1165(1). https://doi.org/10.1088/1742-6596/1165/1/012015

Cleovoulou, Y., \& Beach, P. (2019). Teaching critical literacy in inquiry-based classrooms: Teachers' understanding of practice and pedagogy in elementary schools. Teaching and Teacher Education, 83, 188-198. https://doi.org/10.1016/j.tate.2019.04.012 
Dobber, M., Zwart, R., Tanis, M., \& van Oers, B. (2017). Literature review: The role of the teacher in inquiry-based education. Educational Research Review, 22, 194-214. https://doi.org/10.1016/j.edurev.2017.09.002

Elfizon, Syamsuarnis, \& Candra, O. (2017). THE EFFECT OF STRATEGY OF TRAINING MODELS IN LEARNING ELECTRICAL INSTALLATION. Proceeding of 4th International Conference on Technical and Vocation Education and Training Padang, 8(1).

Eliza, F., Suriyadi, S., \& Yanto, D. T. P. (2019). Peningkatan Kompetensi Psikomotor Siswa Melalui Model Pembelajaran Project Based Learning ( PjBL ) di SMKN 5 Padang: PDS Project. INVOTEK: Jurnal Inovasi Vokasional Dan Teknologi, 19(2).

Hamdani, H., Yanto, D. T. P., \& Maulana, R. (2019). Validitas Modul Tutorial Gambar Teknik dan Listrik dengan Autocad. INVOTEK: Jurnal Inovasi Vokasional Dan Teknologi, 19(2), 83-92. https://doi.org/10.24036/invotek.v19i2.491

Hong, J. C., Tsai, C. R., Hsiao, H. S., Chen, P. H., Chu, K. C., Gu, J., \& Sitthiworachart, J. (2019). The effect of the "Prediction-observation-quiz-explanation" inquiry-based e-learning model on flow experience in green energy learning. Computers and Education, 133(September 2018), 127-138. https://doi.org/10.1016/j.compedu.2019.01.009

Hsu, Y. S., Wang, C. Y., \& Zhang, W. X. (2017). Supporting technology-enhanced inquiry through metacognitive and cognitive prompts: Sequential analysis of metacognitive actions in response to mixed prompts. Computers in Human Behavior, 72, 701-712. https://doi.org/10.1016/j.chb.2016.10.004

Jiang, Y., Clarke-Midura, J., Keller, B., Baker, R. S., Paquette, L., \& Ocumpaugh, J. (2018). Note-taking and science inquiry in an open-ended learning environment. Contemporary Educational Psychology, 55(August), 12-29. https://doi.org/10.1016/j.cedpsych.2018.08.004

Kant, J. M., Scheiter, K., \& Oschatz, K. (2017). How to sequence video modeling examples and inquiry tasks to foster scientific reasoning. Learning and Instruction, 52, 46-58. https://doi.org/10.1016/j.learninstruc.2017.04.005

McNew-Birren, J., \& van den Kieboom, L. A. (2017). Exploring the development of core teaching practices in the context of inquiry-based science instruction: An interpretive case study. Teaching and Teacher Education, 66, 74-87. https://doi.org/10.1016/j.tate.2017.04.001

Riduwan. (2010). Skala Pengukuran Variabel-Variabel Penelitian. Bandung: Alfabeta.

Rolim, V., Ferreira, R., Lins, R. D., \& Găsević, D. (2019). A network-based analytic approach to uncovering the relationship between social and cognitive presences in communities of inquiry. Internet and Higher Education, 42(January), 53-65. https://doi.org/10.1016/j.iheduc.2019.05.001

Suárez, Á., Specht, M., Prinsen, F., Kalz, M., \& Ternier, S. (2018). A review of the types of mobile activities in mobile inquiry-based learning. Computers and Education, 118(November 2017), 38-55. https://doi.org/10.1016/j.compedu.2017.11.004

Sugiyono. (2018). Metode Penelitian Kuantitatif, Kualitatif dan R\&D. Bandung: Alfabeta.

Sukardi, S., Puyada, D., Wulansari, R. E., \& Yanto, D. T. P. (2017). The validity of interactive instructional media on electrical circuits at vocational high school and technology. The 2nd INCOTEPD, 2017, 21-22.

Takeuchi, H., Masuda, S., Miyamoto, K., \& Akihara, S. (2018). Obtaining Exhaustive Answer Set for Q\&A-based Inquiry System using Customer Behavior and Service

Oriza Candra, UsImeldi, Doni Tri Putra Yanto, Femypadillah Ismanto, Pengembangan Perangkat Pembelajaran Berbasis Praktikum Inkuiri Untuk Mata Pelajaranmenganalisis Rangkaian Listrik 
Function Modeling. Procedia Computer Science, 126, 986-995. https://doi.org/10.1016/j.procS.2018.08.033

Teig, N., Scherer, R., \& Nilsen, T. (2018). More isn't always better: The curvilinear relationship between inquiry-based teaching and student achievement in science. Learning and Instruction, 56(October 2017), 20-29. https://doi.org/10.1016/j.learninstruc.2018.02.006

Theobald, K. A., \& Ramsbotham, J. (2019). Inquiry-based learning and clinical reasoning scaffolds: An action research project to support undergraduate students' learning to 'think like a nurse.' Nurse Education in Practice, 38(September 2018), 59-65. https://doi.org/10.1016/j.nepr.2019.05.018

Thuneberg, H. M., Salmi, H. S., \& Bogner, F. X. (2018). How creativity, autonomy and visual reasoning contribute to cognitive learning in a STEAM hands-on inquirybased math module. Thinking Skills and Creativity, 29(July), 153-160. https://doi.org/10.1016/j.tsc.2018.07.003

Yanto, D. T. P., Astrid, E., Hidayat, R., \& Islami, S. (2019). Analisis Uji Kelayakan Trainer Kit Elektronika Daya: 3 Phase Half-Wave and Full-Wave Uncontrolled Rectifier. Jurnal Teknik Elektro Dan Vokasional, 5(1.1), 121-125.

Yanto, D. T. P., Sukardi, S., \& Puyada, D. (2017). Effectiveness of Interactive Instructional Media on Electrical Circuits Course: The Effects on Students Cognitive Abilities. Proceedings of 4rd International Conference On Technical And Vocational Education And Training, 2017, 75-80.

Zhang, L. (2019). "Hands-on" plus "inquiry"? Effects of withholding answers coupled with physical manipulations on students' learning of energy-related science concepts. Learning and Instruction, 60(September 2017), 199-205. https://doi.org/10.1016/j.learninstruc.2018.01.001 